\title{
GAMBARAN KADAR ALBUMIN SERUM PADA VEGETARIAN LACTO-OVO
}

\author{
${ }^{1}$ Frans A. K. Pongsibidang \\ ${ }^{2}$ Murniati Tiho \\ ${ }^{2}$ Stefana H.M. Kaligis
}

\author{
${ }^{1}$ Kandidat Skripsi Fakultas Kedokteran Universitas Sam Ratulangi Manado \\ ${ }^{2}$ Bagian Biokimia Fakultas Kedokteran Universitas Sam Ratulangi Manado \\ Email: franskana.fk@gmail.com
}

\begin{abstract}
Vegetarian lacto-ovo is one of three large groups of vegetarians, where this type eating vegetable foodstuffs and abstained all kinds of meat, but still consumes milk and eggs. Vegetarian diet which regularly planned well, provide many health benefits. On the other hand, vegetarian potentially at risk of suffering from various diseases macro and micro nutrient deficiencies, for example, is protein. Albumin, which is one of the three major groups of plasma protein, globulin and fibrinogen in addition, contributes up to $80 \%$ of the osmotic pressure of plasma. Albumin can be obtained from meat, eggs, soy beans, nuts, and seeds. The levels of serum albumin is an important prognostic indicators because there is a correlation between the levels of serum albumin with increased risk of morbidity and mortality. Methods: The purpose of this study is to describe serum albumin levels in lacto-ovo vegetarians. This cross-sectional study was conducted in September 2015- January 2016. Sampling using total sampling method performed at the University of Klabat Airmadidi, with 25 respondents. Results: From the results of laboratory tests, 20 subjects (80\%) with normal serum albumin levels, and 5 subjects (20\%) with high levels of serum albumin. Conclusion: Based on the results, we can conclude that serum albumin levels in lacto-ovo vegetarian mostly normal.
\end{abstract}

Keywords: lacto-ovo vegetarian, protein, serum albumin

\begin{abstract}
Abstrak: Vegetarian lacto-ovo merupakan salah satu dari tiga kelompok besar vegetarian, dimana tipe ini mengonsumsi bahan pangan nabati dan berpantang makan segala jenis daging, namun masih mengonsumsi susu dan telur. Diet vegetarian yang teratur terencana dengan baik memberikan banyak manfaat kesehatan. Di sisi lain, vegetarian berpotensi berisiko menderita berbagai penyakit defisiensi nutrisi mikro dan makro, contohnya adalah protein. Albumin yang merupakan salah satu dari 3 kelompok besar protein plasma, selain globulin dan fibrinogen, berperan hingga 80\% terhadap tekanan osmotik plasma. Albumin dapat diperoleh dari daging, telur, kacang kedelai, kacang-kacangan, dan biji-bijian. Kadar albumin serum merupakan indikator prognostik penting karena terdapat korelasi antara kadar serum albumin dengan peningkatan risiko morbiditas dan mortalitas. Tujuan penelitian ini untuk mengetahui gambaran kadar albumin serum pada vegetarian lacto-ovo. Metode: Penelitian cross-sectional ini dilakukan pada bulan September 2015 - Januari 2016. Pengambilan sampel dengan metode total sampling dilakukan di Universitas Klabat Airmadidi, dengan jumlah responden 25 orang. Hasil: Berdasarkan hasil pemeriksaan laboratorium didapatkan 20 subyek (80\%) dengan kadar albumin serum normal, dan 5 subyek (20\%) dengan kadar albumin serum tinggi. Simpulan: Berdasarkan hasil tersebut dapat disimpulkan bahwa gambaran kadar albumin serum pada vegetarian lacto-ovo sebagian besar normal.
\end{abstract}

Kata kunci: vegetarian lacto-ovo, protein, albumin serum 
Sejak berabad-abad sebelum Masehi, telah dilakukan pola makan nabati atau lebih dikenal sebagai diet vegan. ${ }^{1}$ Istilah vegan pertama kali diperkenalkan pada tahun 1944 sebagai vegetarian yang hidup dengan mengonsumsi makanan nabati, tanpa makanan hewani termasuk susu dan telur. ${ }^{2}$ Berbagai praktek diet vegetarian telah diidentifikasi mulai dari diet makrobiotik yang paling ketat, diikuti vegan dan diet lacto-ovo vegetarian, sampai mereka yang kadang masih mengonsumsi ikan atau bahkan ayam. $^{3}$

Vegetarian lacto-ovo merupakan salah satu dari tiga kelompok besar vegetarian menurut International Vegetarian Union. ${ }^{1}$ Lacto-ovo vegetarian merupakan tipe vegetarian yang paling umum dijumpai. Tipe ini mengonsumsi bahan pangan nabati dan berpantang makan segala jenis daging, namun masih mengonsumsi telur dan susu beserta produk olahannya. ${ }^{3}$

Saat ini di dunia termasuk Indonesia, semakin banyak orang yang menjadi vegetarian. Hasil survey American Dietetic Association (ADA) menunjukkan pada tahun 2006 jumlah vegetarian dewasa di Amerika sekitar 4,9 juta (2,3\%) penduduk dan di Kanada sekitar 900 penduduk dewasa menjadi vegetarian. Berdasarkan data dari Indonesia Vegetarian Society (IVS), jumlah vegetarian di Indonesia yang terdaftar pada tahun 1998 sekitar 5000 anggota dan pada tahun 2000 meningkat menjadi 60.000 anggota. ${ }^{4}$ Golongan wanita, anak muda dan remaja, kelompok kulit hitam, dan etnik minoritas, serta kelompok social ekonomi yang tinggi, paling sering menjadi kelompok vegetarian. ${ }^{5}$

Beberapa studi menunjukkan bahwa diet vegetarian dapat memperpanjang umur karena mengurangi risiko terhadap penyakit kronik dibandingkan diet nonvegetarian. ${ }^{6}$ Dalam buku Miracle of Vegan oleh Susianto, dipaparkan diet vegetarian dapat mencegah berbagai penyakit seperti penyakit jantung, diabetes, hipertensi, kanker, osteoporosis dan demensia. ${ }^{1} \mathrm{Hal}$ tersebut sejalan dengan penelitian Philips dkk yang menunjukkan diet vegetarian berhubungan dengan berkurangnya angka mortalitas disebabkan oleh cardiovascular disease dan risiko rendah terhadap beberapa kanker. ${ }^{3}$ Pendapat lain mengungkapkan bahwa dengan menjadi vegetarian dapat mengurangi pemanasan global. ${ }^{1}$

Diet vegetarian yang teratur terencana dengan baik memberikan banyak manfaat kesehatan. Di sisi lain, vegetarian berpotensi berisiko menderita berbagai penyakit defisiensi nutrisi mikro dan makro. $^{7}$ Salah satunya ialah protein, dimana protein merupakan salah satu nutrien penting pada vegetarian. Protein sangat penting sebagai sumber asam amino untuk pertumbuhan dan perbaikan jaringan danuntuk sintesis enzim dan hormon. ${ }^{3}$

Protein merupakan makromolekul yang mempunyai beragam peran penting, baik secara fisik maupun fungsional. Sekitar 7,0-7,5 g/dL protein total terkandung dalam plasma manusia dan membentuk bagian terbesar dari bahan padat plasma. Protein plasma merupakan campuran kompleks yang mencakup protein-protein sederhana dan protein terkonyugasi, misalnya glikoprotein dan lipoprotein. Protein plasma dapat dipisahkan menjadi tiga kelompok besar: fibrinogen, globulin,dan albumin. ${ }^{8}$

Albumin (69kDa) membentuk sekitar $60 \%$ protein plasma total dan berperan sebagai protein utama dalam plasma manusia (3,4-4,7 g/dL). Sekitar 60\% albumin terdapat di ruang ekstrasel dan $40 \%$ sisanya terdapat dalam plasma. Albumin dihasilkan oleh hati sekitar 12 g/hari, yaitu sekitar 25\% dari semua sintesis protein oleh hati dan separuh jumlah sekresi protein. ${ }^{8}$

Albumin dapat berikatan dengan berbagai ligan, misalnya asam lemak bebas (FFA), bilirubin, kalsium, hormon steroid tertentu, dan sebagian triptofan plasma, dimana hal ini merupakan salah satu fungsi penting dari albumin. Berbagai obat dapat berikatan dengan albumin termasuk sulfonamide, penisilin G, dikumarol, dan aspirin. $^{8}$

Penelitian cross-sectional oleh Farzana dkk pada 122 sampel (66 vegetarian dan 66 
non-vegetarian) di Bangladesh menunjukkan kadar albumin pada vegetarian lebih rendah dibandingkan dengan non-vegetarian, tapi dalam batas normal. $^{7}$ Hal tersebut sejalan dengan penelitian Caso dkk yang menunjukkan kadar albumin rendah pada sampel yang predominan mengonsumsi diet vegetarian, dikarenakan berkurangnya sintesis albumin. ${ }^{9}$

Uraian dalam latar belakang telah memberi dorongan bagi penulis untuk melakukan penelitian mengenai gambaran kadar albumin pada vegetarian lacto-ovo.

\section{METODE PENELITIAN}

Penelitian yang dilakukan merupakan penelitian deskriptif dengan desain penelitian cross sectional. Penelitian dilaksanakan di Universitas Klabat Airmadidi pada bulan September sampai Januari 2016. Populasi penelitian yaitu semua orang yang menjalani diet vegetarian lacto-ovo. Populasi terjangkau atau sampel penelitian ialah mahasiswa yang menjalani diet vegetarian lacto-ovo di Universitas Klabat yang memenuhi kriteria inklusi. Sampel darah mahasiswa vegetarian lacto-ovo akan diambil dengan cara total sampling.

\section{HASIL PENELITIAN}

Jumlah populasi penelitian yang ditemukan, yakni mahasiswa vegetarian lacto-ovo Universitas Klabat Airmadidi berjumlah 25 orang dengan rentang usia 15 tahun sampai 32 tahun. Seluruh populasi yang memenuhi kriteria inklusi dan kriteria eksklusi dijadikan sampel pada penelitian ini.

Berdasarkan jenis kelamin, sampel terbanyak dalam penelitian ini berjenis kelamin laki-laki berjumlah 14 orang (56\%) sedangkan yang berjenis kelamin perempuan berjumlah 11 orang (44\%). Berdasarkan usia, proporsi terbanyak didapatkan pada umur 21-24 tahun dengan persentase masing-masing $12 \%$, diikuti pada umur 26,27 dan 29 tahun dengan persentase masing-masing $8 \%$, dan terakhir dengan persentase masing-masing 4\% pada umur 15, 18, 19, 20, 25, 30, dan 32 tahun.

Berdasarkan hasil pemeriksaan laboratorium kadar albumin serum, didapatkan sebanyak 20 orang (11 laki-laki dan 9 perempuan) dengan kadar albumin normal, sedangkan terdapat 5 orang (3 lakilaki dan 2 perempuan) dengan kadar albumin tinggi, dan tidak didapatkan kadar albumin rendah pada pemeriksaan sampel. Nilai mean atau rata-rata hasil pemeriksaan kadar albumin pada penelitian ini adalah 4,56 $\mathrm{g} / \mathrm{dL}$, dengan nilai standar deviasi yaitu 0,291548. Nilai median dan nilai modus yang didapatkan yaitu 4,5 g/dL. Nilai range pada hasil pemeriksaan kadar albumin serum didapatkan nilai minimum yaitu 4,00 g/dL dan nilai maksimum yaitu $5,00 \mathrm{~g} / \mathrm{dL}$.

\section{BAHASAN}

Dari hasil pengolah data univariat didapatkan nilai rata-rata hasil pemeriksaan laboratorium kadar albumin serum pada seluruh sampel yaitu 4,56 g/dL. Pada penelitian ini, rata-rata kadar albumin serum pada kelompok yang berjenis kelamin laki-laki yaitu 4,65 g/dL, sedangkan rata-rata kadar albumin serum pada kelompok perempuan yaitu 4,45 g/dL. Jenis kelamin dapat mempengaruhi kadar albumin serum seseorang. Hal ini disimpulkan melalui penelitian eksperimental oleh Anna dkk pada 36 sampel (19 laki-laki dan 17 perempuan) pada tahun 2007. Penelitian ini menemukan bahwa kadar albumin serum laki-laki lebih tinggi dibandingkan perempuan. Penelitian tersebut juga menyimpulkan bahwa ratarata laju sintesis albumin laki-laki (14,8 \pm 4,9\%/d) lebih tinggi dibandingkan perempuan (11,5 \pm 4,8\%/d). Temuan tersebut mungkin dikaitkan bahwa laki-laki memiliki set point untuk kadar albumin yang lebih tinggi dibandingkan perempuan, oleh karena itu laki-laki memiliki laju sintesis albumin yang lebih tinggi. ${ }^{10}$

Rata - rata usia sampel penelitian ini adalah 23,72. Pada penelitian ini ditemukan umur dapat mempengaruhi kadar albumin 
serum. Terdapat kontroversi mengenai hubungan umur terhadap kadar albumin serum. Penelitian oleh Watanabe dkk pada 7715 sampel (3220 laki-laki dan 4495 perempuan, usia lebih dari 30 tahun) di Jepang pada tahun 2010 menunjukkan secara signifikan tidak adanya korelasi antara umur dengan kadar albumin serum dalam darah. ${ }^{11}$ Penelitian ini didukung oleh penelitian Anna dkk pada 63 sampel dengan rentang usia 21-43 tahun dan 63-79 tahun. Penelitian ini juga menunjukkan umur seseorang tidak mempengaruhi kadar albumin serum dalam darah. ${ }^{10}$ Namun, hal tersebut berbeda dengan studi cohort yang dilakukan Motoko dkk selama 7 tahun dengan 36,674 sampel di Jepang. Hasil dari studi tersebut menunjukkan kadar albumin menurun seiring dengan bertambahnya usia. $^{12}$ Penelitian ini mendukung studi longitudinal Ikuko dkk selama 5 tahun pada 62.854 sampel di Jepang. Penelitian ini menunjukkan usia secara signifikan berpengaruh terhadap kadar albumin serum. Data dari kedua penelitian tersebut menunjukkan kadar albumin serum menurun seiring dengan bertambahnya usia, terutama pada lansia. ${ }^{13}$

Pada penelitian ini, terdapat 20 responden dengan kadar albumin normal dengan persentase $80 \%$. Temuan penelitian ini mendukung penelitian yang dilakukan oleh Farzana dkk tahun 2013 pada 122 sampel (66 vegetarian dan 66 nonvegetarian) di Bangladesh. Penelitian cross-sectional oleh Farzana dkk membandingkan nilai rata-rata kadar biochemicals markers, termasuk albumin, pada kelompok vegetarian dan kelompok non-vegetarian. Hasil dari penelitian tersebut menunjukkan rata-rata kadar albumin pada vegetarian sedikit lebih rendah dibandingkan dengan nonvegetarian, namun keduanya dalam batas normal, yaitu sekitar 4,26 g/dL dan 4,31 $\mathrm{g} / \mathrm{dL}$. Pada penelitian ini juga disimpulkan intake protein vegetarian yang lebih rendah dibandingkan non-vegetarian. Pada penelitian Farzana dkk tersebut disimpulkan bahwa terdapat kesamaan kadar nutrien-nutrien dalam serum, seperti albumin, pada vegetarian dan nonvegetarian, kecuali asupan protein, vitamin B12, asam folat, dan $\beta$-carotene. ${ }^{7}$

Salah satu penyebab kadar albumin serum pada vegetarian lebih rendah dibandingkan non-vegetarian ialah berkurangnya sintesis albumin pada vegetarian. Hal tersebut dibuktikan dalam penelitian eksperimental Caso dkk pada sampel yang diberikan dua jenis diet, yaitu diet kaya protein hewani (animal protein rich/ diet A) yang mengandung 74\% protein hewani dan diet kaya protein nabati (vegetables protein rich/ diet V) yang mengandung $67 \%$ protein nabati. Hasil dari penelitian ini menunjukkan kadar albumin pada sampel penelitian yang merupakan pria sehat pada kelompok yang mengonsumsi diet $\mathrm{V}$ kelompok lebih rendah dibandingkan kelompok yang mengonsumsi diet protein hewani dominan, dikarenakan pengurangan sintesis albumin. Dari hasil perhitungan data, diet vegetarian dominan (diet V) mengakibatkan penurunan rata-rata pada sintesis albumin sebesar $12-13 \%$. Sintesis albumin dapat dipengaruhi oleh berbagai kontribusi relatif dari protein hewani dan protein nabati dalam diet. Kedua diet tersebut walaupun ekivalen dalam hal kandungan makronutrien, termasuk jumlah protein secara kasar, kedua diet protein tersebut berbeda dalam hal kualitas. Hal ini disebabkan diet vegetarian dominan memiliki kandungan asam amino yang lebih sedikit dan kemampuan untuk dicerna yang lebih rendah dibandingkan diet protein hewani. ${ }^{9}$

Kadar albumin serum merupakan indikator prognostik penting karena terdapat korelasi antara kadar serum albumin yang rendah dengan peningkatan risiko morbiditas dan mortalitas. ${ }^{14}$ Berbagai kondisi seperti luka bakar, penyakit hati, sindrom malabsorpsi, dan malnutrisi sering dihubungkan dengan kadar albumin yang rendah, sedangkan kondisi yang berhubungan dengan kadar albumin serum yang tinggi ialah diet tinggi protein dan dehidrasi. $^{15}$ 
Pada penelitian ini didapakan 5 responden dengan kadar albumin serum tinggi. Peningkatan kadar albumin dalam serum disebut hiperalbuminemia. Hiperalbuminemia dapat disebabkan beberapa keadaan, seperti diet tinggi protein, dehidrasi, dan pengikatan tourniquet yang terlalu lama saat pengambilan darah sampel. $^{16}$ Pada penelitian ini, diasumsikan hiperalbuminemia yang dialami lima sampel tersebut dikarenakan konsumsi diet tinggi protein. Keadaan dehidrasi dianggap sebagai kriteria tidak sehat yang merupakan kriteria eksklusi pada penelitian ini, sedangkan pengikatan tourniquet yang terlalu lama telah diminimalisir pada saat pengambilan darah sampel sehingga kecil kemungkinan kondisi tersebut menyebabkan hiperalbuminemia pada responden.

Saat ini, konsumsi diet protein tinggi, diatas rekomendasi angka kecukupan gizi protein (RDA: 0,8 protein/kgBB/hari), mengalami peningkatan popularitas, namun belum banyak data mengenai efek samping mengenai diet protein tinggi. ${ }^{17,18}$ Penelitian mengenai efek dari diet tinggi protein telah dilakukan oleh Mutlu dkk pada tahun 2006. Penelitian eksperimental tersebut dilakukan terhadap dua pasien yang diberikan suplemen protein tinggi dan diminta berolahraga untuk kebugaran fisik. Hasilnya setelah olahraga, kedua sampel mengalami hiperalbuminemia, sakit perut intermiten, peningkatan sementara transaminase tanpa ada penyebab yang dapat diidentifikasi. Gejala dan kelainan pada tes laboratorium dapat terselesaikan setelah asupan protein tinggi dihentikan. Temuan tersebut meningkatkan kekhawatiran tentang keamanan diet protein tinggi dikombinasikan dengan latihan intensitas tinggi, sementara patogenesis dan pentingnya kelainan ini belum diketahui dan memerlukan penelitian lebih lanjut. ${ }^{18}$ Keterbatasan pada penelitian ini yaitu tidak dilakukannya rekam data diet responden, sehingga belum diketahui secara pasti apakah responden dengan hiperalbuminemia terbukti mengonsumsi diet tinggi protein.

\section{SIMPULAN}

Dari penelitian pada vegetarian lactoovo di Universitas Klabat Airmadidi mengenai gambaran kadar albumin serum, disimpulkan bahwa sebagian besar (80\%) sampel memiliki kadar albumin serum normal. Dari 25 sampel terdapat 20 sampel dengan persentase $80 \%$ memiliki kadar albumin serum normal dan 5 sampel dengan persentase 20\% memiliki kadar albumin serum tinggi.

\section{DAFTAR PUSTAKA}

1. Susianto. The Miracle of Vegan. Jakarta Selatan: Qanita; 2010. h. 3-6. Available from: https://books. google.nl/books?id=FDNpXqifvnoC \&printsec $=$ frontcover\&hl $=\mathrm{nl} \# \mathrm{v}=$ onep age \&q\&f=false

2. Davis J. World Veganism - Past, Present, dan Future. 2010. h. 1-10. Available from: $\quad$ www.ivu.org/histo ry/Vegan_History.pdf

3. Philips F. Vegetarian Nutrition. British Nutrition Foundation. 2005;30:13267.

4. Siahaan G, Nainggolan E, Lestrina D. Hubungan Asupan Zat Gizi dengan Trigliserida dan Kadar Glukosa Darah pada Vegetarian. Indonesian Journal of Human Nutrition. 2015;2:48-60.

5. Webster-Gandy J, Madden A, Holdsworth M. Gizi dan Dietetika. Edisi ke-2. Hutagalung MSB, Nugroho AW, alih bahasa. Angelina $\mathrm{B}$, Iskandar MT, editor edisi bahasa Indonesia.Jakarta: EGC; 2014. h. 308-12.

6. Department of Nutrition Loma Linda University. The Vegetarian Food Pyramid. 2008 [cited 2015 Oct 15] Available from: www.vegetariannutr ition.org/food-pyramid.pdf

7. Farzana FD, Ahmed S, Ferdous F, Venderlee L, Khan SH, Roy AK, et al. Biochemical and Dietary Indicators among Vegetarians and Non-Vegetarians: Finding from A Cross Sectional Study in Rural Bangladesh. International Journal of 
Nutrition and Food Sciences. 2013;2:130-6.

8. Murray RK. Protein Plasma dan Imunoglobulin. In: Murray RK, Granner DK, Rodwell VW, editors. Biokimia Harper. Edisi ke-27. Pendit BU, alih bahasa. Wulandari N, Rendy L, Dwijayanthi L, Liena, Dany F, Rachman LY, editor edisi bahasa Indonesia. Jakarta: EGC; 2012. p. 22,605-9.

9. Caso G, Scalfi L, Marra M, Covino A, Muscaritoli M, McNurlan MA, et al. Albumin Synthesis Is Diminished in Men Consuming a Predominantly Vegetarian Diet. The Journal of Nutrition. 2000;1:528-33.

10. Thalacker-Mercer AE, Johnson CA, Yarasheski KE, Carnell NS, Campbell WW. Nutrient Ingestion, Protein Intake, and Sex, but Not Age, Affect the Albumin Synthesis Rate in Humans. American Society for Nutrition. 2007;1734-40.

11. Watanabe M, Higashiyama A, Kokubo Y, Ono Y, Okayama A, Okamura T. Protein Intakes and Serum Albumin Levels in a Japanese General Population: NIPPON DATA90. J Epidemiol. 2010;20(Suppl 3):531-6.

12. Miyake M, Ogawa $Y$, Yoshida $Y$, Imaki M. Seven-Year Large Cohort Study For The Association Of Serum Albumin Level And Aging
Community Dwelling Elderly. Journal of Analytical Bio-Science. 2011;34:281-6.

13. Gomi I, Fukushima H, Shiraki M, Miwa Y, Ando T, Takai $K$, et al. Relationship between Serum Albumin Level dan Aging in CommunityDwelling Self-Supported Elderly Population. J Nutr Sci Vitaminol. 2007;53:37-42.

14. Peralta R. Hypoalbuminemia. 01 April 2015 [cited 18 November 2015]. Available from: http://emedicine.medscape.com/articl e/166724-over view \#showall

15. Devaraj S. Albumin. 13 Januari 2015 [cited 18 November 2015]. Available from: http://emedicine. medscape.com/article/2054430-ove rview\#showall

16. Martin LJ. Albumin - Blood (serum) Test. 2 Agustus 2016 [cited 24 Januari 2015]. Available from: https://www.nlm.nih.gov/medlineplus /ency/ article/003480.htm

17. Delimaris I. Adverse Effects Associated with Protein Intake above the Recommended Dietary Allowance for Adults. ISRN Nutrition. 2013;1-6.

18. Mutlu EA, Keshavarzian A, Gokhan M. Hyperalbunemia and Elevated Transaminases Associated with Highprotein Diet. Scandinavian Journal of Gastroenterology. 2006;41:759-60. 